\title{
The Immunomodulatory Effects of Levamisole on Rainbow Trout, Oncorhynchus mykiss
}

\author{
Youichirou KaJita, Masahiro SaKaI, Shizuo Atsuta and Masanori KobaYASHI
}

School of Fisheries Sciences, Kitasato University, Sanriku, Iwate, 022-02 Japan

(Received February 22, 1990)

\begin{abstract}
The immunomodulatory effects of levamisole were investigated using rainbow trout, Oncorhynchus mykiss. Fish sampled 5 days after intraperitoneal injection of levamisole showed increased protection against Vibrio anguillarum when a single dose $(0.5 \mathrm{mg} / \mathrm{kg})$ was used. Phagocytic activity, chemiluminescence responses and natural killer cell activity in fish treated with levamisole were also increased, compared with those in the saline treated fish. Furthermore, levamisole activated the alternative complement pathway of rainbow trout, although serum bactericidal activities against $V$. anguillarum were not enhanced by the treatment of levamisole. These results indicate that levamisole has immunomodulatory effects in rainbow trout.
\end{abstract}

The intensive fish culture system is a highly stressful environment for fish. This stress in fish suppresses the immune responses, and fish kept under these conditions become highly susceptible to fish diseases. Vaccination is a very useful method to increase resistance to disease, but it elicits only specific immunity to one disease. Thus, the increase of nonspecific immunity in stressed fish is important for resistance against many fish diaeases.

The immunostimulants have an ability to increase resistance to disease by enhancing nonspecific defense mechanisms, and many substances have been reported for mammals (CHIHARA, 1980). In fish, the immunostimulant effects of substances such as modified FrEUND's complete adjuvant (containing Mycobacterium butyricum) (Olivier et al., 1985, 1986), a lactoyl tetrapeptide (FK-565) isolated from Streptomyces olivaceogriseus cultures (KITAO and YosHIDA, 1986) and $\beta$-1, 3-glucans (YANO et al., 1989) have been reported, and these substances may be expected to control fish diseases in fish culture.

Levamisole was introduced in 1965 as an anthelmintic for the treatment of nematode infections in man and a variety of animals. Incidental observations suggested a state of enhanced resistance to various kinds of infection in animals that had received such treatment. Animal studies also suggested a stimulatory effect on tumor immunity.

In this study, the immunostimulant effects of levamisole were examined in rainbow trout infected with vibriosis experimentally, and the elicitation of nonspecific defense mechanism by levamisole was investigated.

\section{Materials and Methods}

Fish

Rainbow trout were supplied by the Iwate Prefectural Inland-Water Fisheries Station, Matsuo, Iwate. The mean weights were $10 \mathrm{~g}$ and $50 \mathrm{~g}$. The $50 \mathrm{~g}$ rainbow trout were used in immunological assays and the $10 \mathrm{~g}$ trout in the experimental infection with vibriosis, respectively. These fish were kept at $14^{\circ} \mathrm{C}$ and were fed daily with commercial dry pellets.

\section{Bacteria}

Vibrio anguillarum (strain PT479), a gramnegative fish pathogenic bacterium, was used in the infection experiment. This strain was cultured at $25^{\circ} \mathrm{C}$ for 2 days on Tryptosoya agar (TSA) (Nissui) with $1 \% \mathrm{NaCl}$.

\section{Administration of levamisole}

Levamisole (Takeda) was suspended in saline 
and injected into rainbow trout at a dose of 0.1 $\mathrm{mg}$ to $5 \mathrm{mg}$ per $\mathrm{kg}$ of body weight intraperitoneally. Control fish received an equal volume of saline by the intraperitoneal injection. The fish were kept at $14^{\circ} \mathrm{C}$ with food supplied, and each experiments was carried out 5 days after injection. In the preliminary experiments, the optimal stimulatory dose of levamisole was determined to be $0.5 \mathrm{mg} / \mathrm{kg}$ by using the chemiluminescent response of kidney leukocytes. In this study, a single dose of $0.5 \mathrm{mg}$ levamisole $/ \mathrm{kg}$ was used for experiments.

\section{$L D_{b 0}$ determination}

Trout injected with levamisole or saline were challenged by intraperitoneal injection ranging from 10 to $10^{7}$ cells/fish with a 10 -fold stepwise increase of viable $V$. anguillarum cells suspended in saline. Six individuals were used in each challenge group. After the challenge, fish were maintained at $14^{\circ} \mathrm{C}$ and dead fish were recorded daily for 14 days. All the moribund fish were necrospied and kidney materials were inoculated on TSA with $1 \% \mathrm{NaCl}$.

\section{Serum bactericidal activity}

Serum bactericidal activity was determined by the modified method of IIDA and WAKABAYASHI (1983). The pooled sera from five fish injected with levamisole or saline were diluted 3 times with $0.1 \%$ gelatin-veronal buffer $\left(\mathrm{GVB}^{2+}\right)(\mathrm{pH}$ 7.5 , containing $0.5 \mathrm{~mm} / \mathrm{m} l \mathrm{Mg}^{2+}$ and $0.15 \mathrm{~mm} / \mathrm{m} l$ $\left.\mathrm{Ca}^{2+}\right)$ and then mixed with $V$. anguillarum $(1 \times$ $10^{\circ} \mathrm{CFU} / \mathrm{ml}$ ) suspended in the same buffer at a 1:1 mixing ratio. The mixtures were incubated and shaken for $90 \mathrm{~min}$ at $20^{\circ} \mathrm{C}$, and the number of viable bacteria was calculated by counting the colonies on TSA with $1 \% \mathrm{NaCl}$.

\section{Complement assay}

The serum complement activity was determined by assaying the alternative complement activity $\left(\mathrm{ACH}_{60}\right)$ (YANO et al., 1988). The pooled sera from five fish injected with the levamisole or saline were incubated with rabbit red blood cells (RaRBC) $\left(4 \times 10^{7}\right.$ cells) in $10 \mathrm{~mm}$ EGTA (ethylene glycol-bis tetraacetic acid)-10 mM $\mathrm{MgCl}_{2}-\mathrm{GVB}^{2+}$ (pH 7.0) at $20^{\circ} \mathrm{C}$ for $90 \mathrm{~min}$. The hemolytic activity was measured at O. D. $414 \mathrm{~nm}$ by means of an EIA reader (Bio-Rad) and $\mathrm{ACH}_{50}$ was determined.

\section{Phagocytosis assay}

Five individual fish were used as an experimental or a control group. Phagocytosis assays were examined by the method of SAKAI et al. (1989). Cells were harvested from the fish kidney and minced in RPMI 1640 (Nissui). Cell suspension was centrifuged at $500 \times g$ for $5 \mathrm{~min}$ and washed with the medium. Viable phagocytic cells, including neutrophils and macrophages, were counted by trypan blue exclusion, and the cell number was adjusted to a concentration of $10^{7}$ cells $/ \mathrm{m} l$ with RPMI 1640 medium containing 5\% fetal bovine serum (FBS) (Gibco). Phagocytic cells were stuck onto a coverslide for $1 \mathrm{~h}$ and loose cells were removed by washing with RPMI 1960 medium. The $10^{8}$ latex particles $(0.81 \mu \mathrm{m}$, Difco $)$, suspended in RPMI 1640 medium (5\% FBS), were added to this coverslide and incubated for $2 \mathrm{~h}$ at $20^{\circ} \mathrm{C}$. The coverslide was fixed with methylalcohol and stained with GIEMSA. The number of phagocytizing cells per 300 cells was counted microscopically and the statistical difference was determined by STUDENT's $t$-test.

\section{Chemiluminescence (CL) assay}

Kidney cells were prepared by the method described in the phagocytosis assay, and the cell concentration was adjusted to $10^{7}$ cells in MEM medium without phenol red (Nissui) containing 5 mм HEPES (Wako). $20 \mathrm{mg}$ zymosan A (Sigma) was mixed rainbow trout sera of each group, and reacted at $20^{\circ} \mathrm{C}$ for $30 \mathrm{~min}$. The sera was removed by centrifugation $(800 \times g)$ and zymosan $A$ was suspended in $5 \mathrm{~mm}$ HEPES-MEM medium. Luminol (Katayama) was used to enhance CL response. CL assay was examined according to the modified method of MoRiтOMO et al. (1988). CL activity was measured with 1250 Luminometer (Wallic) for $30 \mathrm{~min}$ at room temperature. In the primary experiment, individual variations were observed, and the kidneys from the individual fish of each group were pooled and CL activities were tested.

\section{Natural killer (NK) cell assay}

In this experiment, three individual fish from each group were used and leukocytes were obtained from the kidney, spleen and peripheral blood 
as effector cells. Leukocutes in each organ were collected by the method described by CLELAND and Sonstegard (1987) and viable leukocytes were counted by trypan blue dye exclusion. A mouse cell line (P815) (H-2b mouse mastocytoma) was used as a target cell line for assaying killer cell activity. The cell line was cultured with RPMI 1640 medium with $10 \%$ FBS.

The same volumes of the target cells $\left(5 \times 1 \mathrm{C}^{4}\right.$ cells $/ \mathrm{m} l)$ and the individual effector cells $\left(5 \times 10^{6}\right.$ cells $/ \mathrm{m} l$ ), suspended in RPMI 1640 , were added to culture tubes and reacted for $6 \mathrm{~h}$ at $20^{\circ} \mathrm{C}$. The percent cytotoxicity was determined by counting dead P815 cells with trypan blue dye exclusion.

$\%$ Cytotoxicity $=$

[(Number of P815 killed by leukocytesnumber of spontaneously dying P815 cells)/ (Number of total P815 cells -

Number of spontaneously dying P815 cells)] $\times 100$

\section{Results}

\section{$L D_{50}$ against $V$. anguillarum}

$\mathbf{L D}_{50}$ values of rainbow trout treated with levamisole or saline against $V$. anguillarum are shown in Table 1. The $L_{50}$ for fish treated with levamisole was about 50 times higher than for saline-treated fish.

Serum bactericidal activities against $V$. anguillarum

The serum bactericidal activities of fish treated with levaminsole or saline are indicated in Table

Table 1. $\mathrm{LD}_{50}$ of Vibrio anguillarum PT479 in rainbow trout with levamisole

\begin{tabular}{cc}
\hline Group & LD $_{50}($ CFU/fish $)$ \\
\hline Levamisole & $2.3 \times 10^{6.17}$ \\
Control & $2.3 \times 10^{4.5}$ \\
\hline
\end{tabular}

Table 2. Bactericidal activities against Vibrio anguillarum PT479 in serum of rainbow trout injected with levamisole

\begin{tabular}{lc}
\hline \multicolumn{1}{c}{ Group } & $\begin{array}{c}\text { Number of bacterial } \\
\text { cells (CFU) }\end{array}$ \\
\hline Levamisole & $1.1 \times 10^{5}$ \\
Control & $1.9 \times 10^{5}$ \\
\hline
\end{tabular}

Table 3. $\mathrm{ACH}_{50}$ values in serum of rainbow trout injected with levamisole

\begin{tabular}{lc}
\hline \hline Group & $\mathrm{ACH}_{50}$ (units/ml) \\
\hline Levamisole & $565 \pm 21$ \\
Control & $354 \pm 50$ \\
\hline
\end{tabular}

Table 4. Phagocytic activities against latex particles in kidney phagocytic cells of rainbow trout injected with levamisole

\begin{tabular}{lcc}
\hline \multicolumn{1}{c}{ Group } & $\begin{array}{c}\text { Phagocytic } \\
\text { activity } \\
(\%)(\mathrm{n}=5)\end{array}$ & Significance \\
\hline Levamisole & $37.85 \pm 4.40$ & $p<0.005$ \\
Control & $19.64 \pm 2.59$ & \\
\hline
\end{tabular}

2. The serum bactericidal activities against $V$. anguillarum were not enhanced in the sera of fish treated with levamisole.

$\mathrm{ACH}_{50}$

The $\mathrm{ACH}_{50}$ value of levamisole-treated fish was $565 \pm 21$, and that of saline-treated fish was $354 \pm 50$ (Table 3). The statistical difference of hemolytic activity is demonstrated by the $\mathrm{ACH}_{50}$ values observed with experimental fish and control fish.

\section{Phagocvtic activities}

The phagocytic activities of kidney cells were $37.85 \pm 4.40$ for levamisole-treated fish, and $19.65 \pm 2.59$ for saline-treated fish (Table 4). The kidney phagocytic cells from fish injected with levamisole showed the increased phagocytic activity $(P<0.005)$.

\section{CL response}

The mean maximum level of the CL response of phagocytic cells in experimental fish reached $208 \mathrm{mV}$ (Fig 1). This value was about 2 times the $\mathrm{CL}$ response of cells from saline treated fish.

\section{NK cell assay}

The NK cell activities of kidney and peripheral blood leukocytes significantly increased in rainbow trout treated with levamisole (Table 5). However, in splenic leukocytes of fish treated with 


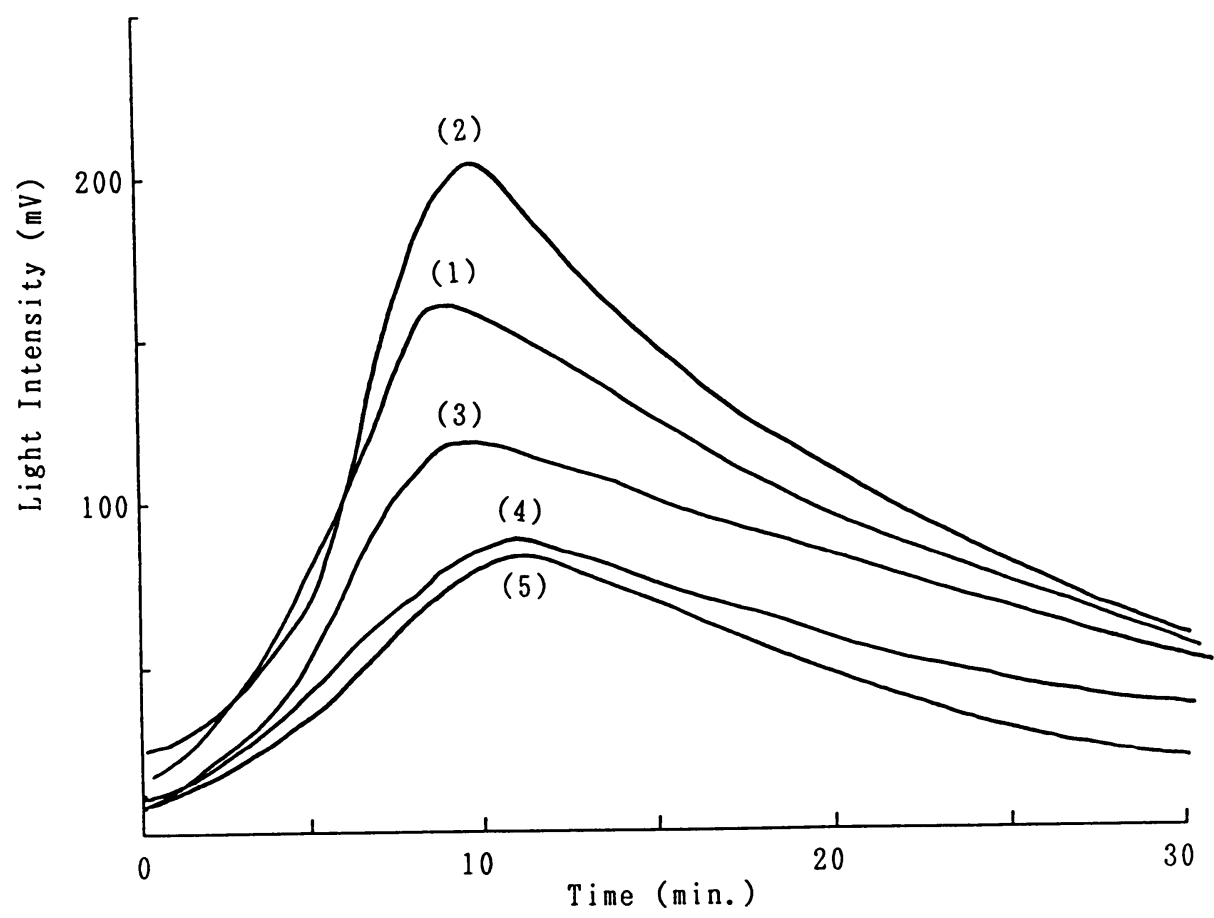

Fig. 1. Chemiluminescent $(C L)$ response in kidney leucocytes of rainbow trout injected with levamisole. $0.1 \mathrm{mg} / \mathrm{kg}$ (1), $0.5 \mathrm{mg} / \mathrm{kg}$ (2), $1 \mathrm{mg} / \mathrm{kg}$ (3), $5 \mathrm{mg} / \mathrm{kg}$ (4), Control (5).

Table 5. Natural killer cell activities against P815 cells in kidney, spleen, or peripheral blood leukocytes of rainbow trout injected with levamisole

\begin{tabular}{llcc}
\hline \hline Lymphocyte & Group & $\begin{array}{c}\text { Natural killer cell } \\
\text { activity }(\%)(\mathrm{n}=3)\end{array}$ & Significance \\
\hline Kidney & Levamisole & $28.80 \pm 4.15$ & $P<0.005$ \\
& Control & $22.25 \pm 1.25$ & N. S. $^{\left.{ }^{\prime}\right)}$ \\
\hline Spleen & Levamisole & $18.80 \pm 3.48$ & $P<0.005$ \\
& Control & $19.89 \pm 1.96$ & \\
\hline Peripheral blood & Levamisole & $20.73 \pm 4.20$ & $13.67 \pm 2.32$ \\
\hline
\end{tabular}

N. S. ${ }^{1)}$; No Significance

levamisole, the enhancement of the activity was not observed. The statistical differences between treated and control froups were demonstrated by the Student $t$-test $(P<0.005)$.

\section{Discussion}

Levamisole in mammals enhances the metabolic and phagocytic activity of neutrophils, and increases the number of phagocytic cells and leukocytes and the level of lysozyme in serum (Symoens and Rosenthal, 1977). In fish, the same effects have already been reported by SIWICKI (1987, 1989). He described that carp injected with levamisole at doses of 5 and 10 $\mathrm{mg} / \mathrm{kg}$ body weight intraperitoneally showed enhanced phagocytic activity and myeloperoxidase activity in neutrophils, and increased leukocyte numbers and serum lysozyme levels. These immunomodulatory effects lasted for 3 months. 
In this study, the $\mathrm{LD}_{50}$ of rainbow trout injected with levamisole against $V$. anguillarum was 50 times higher than of saline-injected fish. This result suggests the possibility of application of levamisole to the control of the disease. Olivier et al. (1985) also reported that coho salmon injected with levamisole showed the enhanced protection against Aeromonas salmonicida. This enhanced protection must be examined in the other fish diseases, including viral diseases.

It is well known that phagocytic cells play an important role in protection against infectious fish diseases (Fllis et al., 1976, Griffin, 1983). KODAMA et al. (1989) reported that the activation of macrophages in carp was demonstrated by a significant increase of the $C L$ response and phagocytic activity when the fish was immunized with $V$. anguillarum. Our results suggest that the phagocytic activities and CL response of phagocytic cells are significantly increased in rainbow trout injected with levamisole. Therefore, it is considered that fish phagocytic cells are activated by levamisole.

Recently, the importance of NK cell in tumor immunity has been indicated. NK activity is increased by agents such as BCG and Corynebacterium parvum which stimulate macrophages (RoITT 1984). NK activity also significantly increased in rainbow trout injected with levamisole. Although the function of NK in fish is still unclear, it might afford the increased protection against viral infection in levamisole-treated fish.

We investigated the hemolytic activity against $\operatorname{RaRBC}\left(\mathrm{ACH}_{50}\right)$ and bactericidal activity against $V$. anguillarum in the serum of fish injected with levamisole as an indicator of nonspecific humoral immunity. Levamisole activated the alternative complement pathway of rainbow trout, although the bactericidal activity against $V$. anguillarum was not enhanced in sera. This activated complement may play an important role in the nonspecific defense mechanism through the promotion of immunological reactions such as opsonic complement effects.

In this study, we indicated that levamisole activated the protection to vibriosis in rainbow trout. The results show that levamisole may be a possible immunomodulatory substance for the immune enhancement to fish disease. Further studies will address oral administration and adjuvant effect of immune response in this substance.

\section{Acknowledgment}

The authors are grateful to Japanese Cancer Research Resources Bank (JCRB) for supplying mouse P-815 cell line.

\section{References}

Chimara, G. (1980): Cancer and Immunopotentiation. Koudansya-Scientific, Tokyo, Japan. (In Japanese.)

Cleland, G. C. and R. A. Sonstegard (1987): Natural killer cell activity in rainbow trout (Salmo gairdneri): Effect of dietary exposure to Aroclor 1254 and/or Mirex. Can. J. Fish. Aquat. Sci., 44, 636-638.

Ellis, A. E., A. L. S. Munro and R. J. Roberts (1976): Defense mechanisms in fish. 1. A study of the phagocytic system and the fate of intraperitoneally injected particulate material in the plaice (Pleuronectes platessa L.). J. Fish Biol., 8, 67-87.

GriffIN, B. R. (1983): Opsonic effects of rainbow trout (Salmo gairdneri) antibody on phagocytosis of Yersinia ruckeri by trout leukocytes. Dev. Comp. Immunol., 7, 253-259.

IIDA, T. and H. WAKABAYASHI (1983): Bactericidal reaction by the alternative pathway of fish complement. Fish Path., 18, 77-84. (In Japanese with English summary.)

KitaO, T. and Y. Yoshida (1986): Effect of an immunopotentiator on Aeromonas salmonicida infection in rainbow trout (Salmo gairdneri). Vet. Immun. Immunopathol., 12, 287-291.

Kodama, H., F. Yamada, T. Murai, Y. Nakanishi, T. MIKAMI and H. IzAWA (1989): Activation of trout macrophages and protection of carp after immunization with Vibrio anguillarum. Dev. Comp. Immunol., 13, 123-132.

Moritomo, T., T. IIDA and H. WAKABAYASHI (1988): Chemiluminescence of neutrophils isolated from peripheral blood of eel. Fish Path., 23, 33-40.

Olivier, G., T. P. T. Evelyn and R. LALlier (1985): Immunity to Aeromonas salmonicida in coho salmon (Oncorhynchus kisutch) induced by modified FreUnD's complete adjuvant: Its non-specific nature and the probable role of macrophage in the phenomenon. Dev. Comp. Immunol. 9, 419-432.

Olivier, G., C. A. Eaton and N. Campbell (1986): Interaction between Aeromonas salmonicida and and peritoneal macrophages of brook trout (Salvelinus fontinalis). Vet. Immunol. Immunopathol., 
12, 223-234.

RoITT, I. M. (1984): Essential immunity. 5th ed. Blackwell Scientific Publications, Oxford, England.

Sakai, M., S. Atsuta and M. Kobayashi (1989): Protective immune response in rainbow trout, Oncorhynchus mykiss, vaccinated with $\beta$-hemolytic streptococcal infection. Fish Path., 24, 169-173.

SIWICKI, A. (1987): Immunomodulating activity of levamisole in spawners carp (Cyprinus carpio L.). J. Fish Biol., 31, Supplement A.

SIwICKI, A. (1989): immunostimulating influence of levamisole nonspecific immunity in carp (Cyprinus carpio L.). Dev. Comp. Immunol., 13, 87-91.

Symoens, I. and M. Rosenthal (1977): Levamisole in the modulation of the immune response. The current experimental and clinical state. $J$. Reticuloendothel. Soc., 21, 175-221.

Yano, T., Y. Hatayama, H. Matsuyama and M. NAKAO (1988): Titration of the alternative complement pathway activity of representative cultured fishes. Nippon Suisan Gakkaishi, 54, 1049-1054. (In Japanese with English summary.)

Yano, T., R. E. P. MangindaAn and H. Matsuyama (1989): Enhancement of the resistance of carp, Cyprinus carpio, to experimental Edwardsiella tarda infection, by some $\beta$-1, 3-glucans. Nippon Suisan Gakkaishi, 55, 1815-1819. 